\title{
Kudy z krize? Komunitarismus proti liberalismu po česku*
}

\author{
Jiří Přibáň: Obrana ústavnosti aneb Česká otázka v postnacionální Evropě \\ Praha, Sociologické nakladatelství (SLON) 2014, 266 s. \\ Petr Drulák: Politika nezájmu: Česko a Západ v krizi \\ Praha, Sociologické nakladatelství (SLON) 2012, 323 s.
}

Podle řady reflexí současnosti se moderní společnost jako celek i její jednotlivé národně specifické interpretace dostávají do krize. Ta podle různých autorů nabývá různých podob od finanční až po hluboce morální. Mnohosti diagnóz odpovídá mnohost návrhư řešení. $V$ následujících třech příspěvcích se zaměřujeme na některé $\mathrm{z}$ nich a prezentujeme je jako svého druhu obdobu vlivné debaty mezi liberály a komunitaristy, která se před několika desetiletími - také v souvislosti s krizí, kterou přinesl konec poválečného kompromisu mezi demokracií a kapitalismem - rozhořela $\mathrm{v}$ angloamerické politické a sociální teorii.

Nacházíme se v období, které vyžaduje revoluční řešení zpochybňující základy liberálního státu, občanské společnosti a soutěživé demokracie, jak jsme si o nich zvykli v posledních pětadvaceti letech přemýšlet? I v české diskusi nacházíme obhájce kladné odpovědi. Řada jiných autorů ale přichází se zcela odlišnými odpověd'mi. Vedle liberáli̊, které nijak nelze redukovat na obhájce volného trhu (jak jsme si na to také zvykli v minulých desetiletích), na něž především se zaměřuje tento příspěvek, se jedná také o ty, kteří obecně komunitaristickou ideu jako součást liberální demokracie akcentují, ale kritizují její různá konkrétní provedení (druhý příspěvek), a také o kritičtěji orientované přístupy, skrze které debatuje poslední text $\mathrm{v}$ této sekci recenzních esejů.

\section{Individuální vs. skupinová práva}

Když v roce 1971 John Rawls publikoval svou Teorii spravedlnosti [Rawls 1971], snažil se v ní - podobně jako když lingvista systematizuje gramatiku jazyka - systematizovat naše morální intuice. V protikladu ke studenoválečnickému liberalismu jeho předchůdců F. A. Hayeka a I. Berlina, kteří proti jimi vnímanému nebez-

\footnotetext{
* Text vznikl v rámci Programu rozvoje vědních oblastí na Univerzitě Karlově (PRVOUK), P17 „Vědy o společnosti, politice a médiích ve výzvách doby“, řešeném na Fakultě sociálních věd Univerzity Karlovy v Praze.
} 
pečí totalitarismu, postavili úzce chápanou, formální (negativní) svobodu, podle Rawlse v těchto intuicích najdeme také víru v rovnost přiležitostí a elementární materiální zabezpečení. Přes všechny diskuse, které se kolem jeho dvou principů spravedlnosti rozhořely, je zřejmé, že Rawls nadále nevěři v to, že svobodným člověk může být jen na základě formálně zajištěných občanských práv. Pokud nemá příležitost a prostředky těchto práv využít, jedná se jen o prázdný příslib.

Excesivní nerovnosti a uzavřené př́ležitosti $\mathrm{k}$ tomu, aby i neprivilegovaní mohli dosáhnout na zdroje (dnes nejvíce asi vzdělání), které by jim umožnily ve společnosti zaujmout místo nikoli podle jejich sociálního původu, ale podle jejich schopností a investovaného úsilí, ničí předpoklady spravedlivé společnosti. Zjednodušeně můžeme říci, že se v Rawlsově teorii snoubí respekt k občanským právům s právy sociálními, nebo ještě jednodušeji: požadavky svobody a morální rovnosti. Tento respekt $\mathrm{v}$ pojetí Rawlse a dalších kantovských liberálů druhé poloviny 20. století (napřr raného R. Dworkina) nemůže vyrůstat z nějaké konkrétní obsahové koncepce dobrého života, naopak musí stát nad všemi konkrétními koncepcemi a poskytovat jim obecný rámec. Stát má v tomto pojetí být eticky co nejvíce neutrální, zajistit vymahatelnost práva, rozumnou rovnost př́iležitostí a redistribuci zdrojů, která bude systematicky z chudoby vytahovat ty, kteří neuspěli v kapitalistické soutěži.

V otázkách ústavního uspořádání a základní spravedlnosti klade liberalismus důraz na etickou neutralitu státu jako základní podmínku toho, že individuální práva jednotlivců nejsou pošlapávána, ale je jim poskytován rovný ohled. Eticky neutrální pravidla práva nikomu neříkají, jaký život by měl žít, ale poskytují obecnou kostru základních principů, v jejímž rámci je každému umožněno, aby sledoval vlastní cíle (své koncepce dobrého života). Eticky neutrální stát je tak schopen dostát základnímu liberálnímu požadavku, kterým je rovný ohled k individuálním životním projektům. Liberálové mluví o přednosti práva před dobrem. Kdyby totiž společenství bylo založeno na nějaké konkrétní představě o tom, jaký život stojí za to žít, a protěžovalo by tuto představu ve veřejném životě, diskriminovalo by ty jedince, kteří by se s takto propagovanou koncepcí neztotožňovali. Podle liberálů pouze eticky neutrální rámec (resp. založený na „slabé koncepci dobra“ - viz níže) spravedlivých pravidel zajištuje relativně nekonfliktní soužití v moderní pluralitní společnosti (zde a ve zbytku této sekce vycházím z Císař [2005]).

Liberalismus Rawlse a dalších rovnostářských liberálů byl následně podroben kritice ze strany heterogenní skupiny myslitelů, které označujeme jako komunitaristy (k jejich definici viz např. Mulhall a Swift [1992], Barša [1995]). Zjednodušeně řečeno, komunitaristé (jen pro ilustraci srov. např. MacIntyre [(1981) 2004], Sandel [1982, 1996], Walzer [1983], Taylor [(1989) 1997, (1992) 2001]) liberální pojetí nepřijímají a tvrdí, že není možné založit žádnou politickou komunitu na takové vyprázdněné koncepci. Podle nich základní pravidla uspořádání společnosti vždy předpokládají určitou koncepci dobrého života, která dané společenství charakterizuje. Komunitaristé proto proti liberální neutralitě a individua- 
lismu staví důraz na společné hodnoty sdílené všemi členy společnosti a namísto liberálních svobod zdưrazňují sociální zapuštěnost člověka v životě konkrétní pospolitosti. Jiným jazykem řečeno, svobodu a morální rovnost podmiňují bratrstvím sdíleným např́ič komunitou.

Např́ílad Adam Swift [(2001) 2005] shrnuje komunitaristické výtky do sedmi bodů. Podle komunitaristického přesvědčení liberálové: (1) předpokládají, že lidé jsou sobečtí a egoističtí, (2) obhajují minimální stát, (3) na úkor povinností zdůrazňují práva, (4) jsou hodnotovými relativisty, (5) popírají sociální charakter individuální identity, (6) atomizují společnost a (7) mylně věří v neutralitu státu. Swift a s ním řada jiných autorů včetně těch, které nominálně řadíme do komunitaristického tábora [např. Taylor (1989) 1997], dokládají, že normativní individualismus liberalismu nutně neimplikuje egoismus či představu atomizované společnosti (tím méně hodnotový relativismus). V liberální doktríně není nic, co by automaticky vedlo $k$ desintegraci společnosti či pohrdání sdílenými hodnotami. Právě naopak: stabilní liberální společnost musí stát na konsensu o společných pravidlech soužití.

Důležité je to, že tato pravidla nesmí vyrůstat z nějaké partikulární doktríny o tom, jak by všichni občané měli žít. $V$ tomto smyslu je liberální představa spravedlivého politického uspořádání založena na jakési "slabé koncepci dobra“, která umožňuje důstojnou existenci i těm, kteří nevyznávají liberální ideál autonomního jedince. V liberální společnosti je místo pro řadu subkultur, které při respektu k základním pravidlům soužití mohou vést řadu velmi protikladných životů.

Komunitaristickou výzvu bere Rawls vážně později ve své koncepci politického liberalismu, kterou jednak partikularisticky podmiňuje existující politickou kulturou západních liberálních demokracií a společně s tím explicitně omezuje její dosah na uspořádání politických institucí [Rawls 1993, v češtině viz Rawls (1985) 1995, (1989) 2003]. Pokud nebudeme liberalismus chápat jako metafyzickou všezahrnující doktrínu, ale jen jako politické lešení, které udržuje pluralitní společenskou budovu naší společnosti, měl by být přijatelný nejen pro liberály, ale také pro komunitaristy, kteří před individuální svobodou upřednostňují její skupinovou sestřenici. V tomto smyslu má být politický liberalismus schopen pojmout také nároky např́klad náboženských skupin, které liberální ideál uspořádání společnosti nevyznávají. $V$ současné společnosti, v níž se sváří nekonečné množství koncepcí dobrého života, je podle Rawlse politický liberalismus jedinou metodou, která zároveň zajistí nutný stupeň společenské integrace (konsensus o základních pravidlech) i toleranci neliberálních životních stylů. Ti, kteří se neoddávají liberálnímu ideálu autonomního jedince, k tomu nebudou nuceni, stačí jen, když se s ostatními shodnou na základní osnově politického života.

Rawls tak věril, že se mu podařilo skloubit úctu k jednotlivci i skupinovým odlišnostem. Podle něj totiž jen individuální práva mohou zajistit, aby byla malá skupina chráněna před netolerancí ze strany širší společnosti. Ve společnosti charakterizované "rozumným pluralismem“ jsou individuální svobody jedinou 
možností, jak může skupina bránit svůj minoritní životní styl (např. náboženství). Pokud by tomu tak bylo, Rawls by byl nalezl lék na palčivý problém dneška. Podle kritiků však politický liberalismus ničeho takového nedosáhl.

Podle Rawlse neliberální skupina může liberální svobody přijmout, protože jí to nijak neublíží. Avšak mezi autonomním rozhodováním jednotlivcư a právem skupiny na sebeurčení může existovat hluboký nesoulad. I když liberální stát nebude individuální autonomii vyžadovat, postačuje, že ji umožňuje [Kymlicka 2002: 239-240]. Již to je v rozporu s kolektivními cíli komunity, která se jako celek nehodlá otevřít vnějším vlivům, nebot’ by to jejím jednotlivým členům umožnilo, aby z ní vystoupili.

Jak zdůrazňuje například W. Kymlicka [ibid.: 228-244], i Rawlsova pozdní koncepce proto stojí na liberálním předpokladu priority individuálních svobod před právem komunity a žádný komunitaristický nárok (který tuto přednost obrací) není z jeho hlediska obhajitelný. Ani politický liberalismus tak komunitaristickým skupinám mnoho nenabízí - neumožňuje podřídit individuální práva požadavkům skupiny - jen upravuje způsob argumentace pro liberální principy. Rawls přijatelnost své koncepce spravedlnosti podmiňuje přistoupením všech rozumných doktrín na „liberální minimum“.

Obecně z toho plyne, že bez ohledu na to, z které strany rozporu začneme, normativně nelze individuální práva s nároky komunity sloučit. Ačkoli to nijak nevylučuje vidět fungující a solidární společnost jako nutný předpoklad smysluplné individuální existence [Taylor (1989) 1997; Swift (2001) 2005], vylučuje to možnost najít soulad mezi nároky jedince a společenství na společné normativní rovině. Jednoduše řečeno, musíme se rozhodnout, jestli za základní princip ospravedlnění politických rozhodnutí a norem budeme považovat jednotlivce (jako liberalismus), nebo skupinu (jako komunitarismus).

\section{Mystický komunitarismus}

Petr Drulák [2012] ve své knize začíná z druhého konce než pozdní Rawls, ale zdánlivě s podobným cílem. Chce najít smír mezi moderními hodnotami - svobodou, rovností a bratrstvím. Bratrství v jeho komunitaristické koncepci hraje zřetelný prim, vytváří samotnou podmínku smysluplné svobody, která se nerealizuje jen v konzumu a morální rovnosti, které nejde jen o to, abychom všichni měli stejně. Zatímco liberalismus upřednostňuje svobodu, která - když je ponechána sama sobě - ústí do světa nerovného a nespravedlivého kapitalismu, a socialismus zase klade důraz na rovnost, která sama o sobě podřizuje člověka donucujícímu státu, v bratrské pospolitosti můžeme najít mezi těmito různými hodnotami rovnováhu. Společenství bratrství - o sestrách se autor nezmiňuje umožňuje podle Druláka svobodnou existenci rovných lidských bytostí.

Jak jsme viděli výše, Drulák se snaží o nemožné - najít a deklarovat rovnováhu mezi požadavky jednotlivce a společenského celku na společné normativ- 
ní úrovni, přičemž ve skutečnosti klade důraz na celek. Výsledkem je koncepce, v níž se nároky jednotlivce rozpouštějí a o nějaké rovnováze nemůže být řeč.

Podle Druláka naší společnosti chybí sdílené předivo, solidarita a v posledku láska mezi jednotlivci. Podobně jako zamilovaný pár, který se ztrácí jeden v druhém, Drulák formuluje koncepci společnosti, kde se jedinci ztrácejí ve vzájemném láskyplném vztahu a společně putují ke spáse (ke společnému účelu - telos). Drulák se tak anachronicky vrací k (aristotelovskému) předmodernímu teleologickému pojetí společnosti, kterou definuje sdílený účel existence (viz také text J. Jüptnera v této sekci). Ten zde doslova spočívá „v mystickém překonání individualismu a vytvoření vztahu mezi konečným jednotlivcem a nekonečnem". Podle Druláka [2012: 10] jen "takto ustavené bratrství umožňuje pospolitosti reflektovat lásku, rozumnost a účel“. Láska a spása tak v Drulákově pojetí ztrácejí soukromý význam a stávají se z nich nejen koncepce veřejné, ale hned politické. Mezi veřejností a politikou se zde systematicky nerozlišuje. Občanská společnost jako sféra veřejnosti ve skutečnosti zcela mizí (viz níže a text $\mathrm{K}$. Müllera v této sekci).

Vzhledem k deklaraci, že mu jde zároveň o liberální koncepci, Drulák pravděpodobně předpokládá, že do láskyplného objetí si členové komunity (národa) padnou dobrovolně, když nahlédnou prázdnotu své pozemské existence. To je ale nepodložený předpoklad, který o to více překvapí u někoho, kdo svou dosavadní kariéru věnoval mezinárodním vztahům. Stejnou vírou totiž pláli katolíci a protestanti předtím, než se na prahu modernity střetli v krvavých konfliktech náboženských válek, během nichž mnoho z nich a další nevinné oběti spolu $\mathrm{s}$ nimi jejich politicky vyjádřená láska $\mathrm{k}$ bohu připravila o život. Asi někde tady začíná moderní teorie mezinárodních vztahů, když v kontextu těchto konfliktů Thomas Hobbes formuluje svou realistickou a zároveň protoliberální koncepci politické moci, stojící nad otázkami nekonečnosti [Barša, Císař 2008]. Politická moc zajištuje mírovou koexistenci, a nikoli spásu. Problémy, s nimiž se tehdy potýkala Evropa, se v současném globalizovaném světě jen stupňují a není jasné, jak by si Petr Drulák představoval naplnění své koncepce mystického komunitarismu v radikálně plurálním prostředí dnešní Evropy. Je zřejmé, že bez násilí by se to opět neobešlo.

Žádný mystický prožitek nemůže být formulován v jednotném čísle pro celou společnost - stejně jako existují různé cesty k pozemskému štěstí, existují různé způsoby vyjadřování lásky k bohu a vztahování se k nekonečnu. Naše společnost je odsouzena nikoli $\mathrm{k}$ jednotě bratrství, ale pluralitě společenstev, jejichž koexistenci může zajistit jen shoda na velmi obecných pravidlech. Petr Drulák možná chce pít z určitého náboženského pramene, jiní ale hledají osvěžení u pramenů jiných a ještě jiní by raději i nadále zírali do mystického prázdna hluboké propasti. Nikoli jedna mystika pospolitosti, ale různé mystiky koexistujících společenstev definují moderní společnost mnohosti. To není z hlediska sociologie nijak novátorský poznatek. Na zachycení tohoto rozdílu se sama disciplína v předminulém století konstituovala. 


\section{Proroci revoluce vs. muži a ženy politické praxe}

Hlasatelem utopie bratrství má podle Druláka [2013] být prorok, který vnese do společnosti nové hodnoty lásky a přátelství. Drulák tak opět nebere vážně doporučení zakladatelů vlastní disciplíny, kteří varovali před zaměňováním veřejných rolí a hodnotových sfér v moderní společnosti jako možné př́činy nikoli společenské obrody, ale politického násilí. Prorok v tomto pojetí patří do kostela, pod širé nebe, do klášterní cely či osamění jeskyně nebo má rozmlouvat s ptáky a starat se o slabé, $\mathrm{v}$ politice ale nemá co dělat. Jak upozornil Max Weber a po něm Hans Morgenthau, v reálném světě proroci, kteří v čele svých revolučních hnutí „právě kázali ,lásku proti násilí', v nejbližším okamžiku k násilí vyzývají k poslednimu násilí, které by prý odstranilo násilí vůbec" [Weber (1919) 1998: 290]. Nikoli prorok se sadou jednoduchých principů, ale politik a politička, kteří jsou schopni předvídat dopady nasazení mocenských prostředků, za jejichž užití nesou odpovědnost, mají rozhodovat o osudech konkrétního společenství.

Taková politika je bratrství mezi lidmi i jejich skupinami nakloněna více než revoluční utopie společné lásky z úst hlasatelů spásy, jejichž rétorika $\mathrm{v}$ dnešním radikálně pluralitním a již tak rozděleném světě daleko více směřuje $\mathrm{k}$ dalším „náboženským válkám“. Veřejný aktér, který chce mluvit za celou společnost, tu není od toho, aby bratrství společensky realizoval, ale pomáhal vytvářet podmínky pro to, aby jeho různé podoby mohli jednotlivci svobodně realizovat sami. Bratrství se nemůže stát politickým úkolem bez toho, aby vedlo $\mathrm{k}$ útlaku dovnitř a intenzifikaci konfliktních hranic mezi lidskými společenstvími.

Právě proto se například podle J. Přibáně [2011: 44] na rozdíl od svobody a rovnosti „ideál bratrství v moderní době nestal politickou možností, ale o to víc zůstal noční můrou politiky [...], v níž morálka splývá s politikou a metafyzické dobro s pozemskou spravedlností. Uvědomit si, že nepř́tele mohu milovat pouze jako křestáan, ale ne jako občan, jehož politickou obec tito nepřátelé ohrožují, $\mathrm{v}$ tom spočívá politická moudrost. Uvědomit si, že v pozemském životě nemohu tento rozpor překonat, $\mathrm{v}$ tom spočívá náboženská moudrost, která vede $\mathrm{k}$ Boží milosti."

\section{Současný liberalismus}

Petr Drulák [2012] má pravdu, když reflektuje převládající jednostranné chápání liberalismu v Česku jako "tržního liberalismu“. Jak přesvědčivě ukazují i empirické výzkumy, díky komunistickému dědictví byl (kulturně-sociální) důraz na individuální autonomii v českém politickém poli hegemonizován pravicovými stranami, které jej ve svých programech spojily s ekonomickým programem „volného trhu“. Zatímco v západní Evropě kulturní liberalismus (důraz na individuální autonomii) koreluje s levicovým ekonomickým programem a kulturní konzervatismus s trhem, v postkomunistických zemích je to naopak - individuální autonomie a lidská práva jsou kulturní dimenzí programu pravicových 
(ekonomicky protržních) stran, kulturní konzervatismus pak jde ruku v ruce s ekonomicky levicovým programem [Marks et al. 2006; Rovny, Edwards 2012].

Egalitářský (rawlsovský) liberalismus, který v sobě obsahuje kulturní dědictví západních antiautoritářských hnutí druhé poloviny 20. století, v takových podmínkách nijak nerozkvétá ani intelektuálně, a jak dokládá osud některých politických stran, ani politicky. Není proto tolik překvapující, že když s českým kontextem srostlý Petr Drulák hledá východiska z jím vnímané krize, kterou podle něj způsobil především tržní liberalismus (v čemž má zřejmě pravdu), s klidným svědomím s vaničkou vylévá i dítě. Jelikož jednodimenzionální ekonomický liberalismus (a žádný jiný zde - snad s výjimkou právních diskusí, viz také níže - politicky artikulován není) podle něj vede ke společenské desintegraci a ztrátě sdíleného smyslu, je třeba liberalismus odmítnout jako takový a nahradit jej radikální alternativou v podobě konzervativně revoluční utopie sdílené lásky.

Jak již dříve publikované polemiky mezi právními experty [např. Přibáň, Holländer et al. 2011], tak nedávno vydaný sborník esejů - publikovaných původně mezi lety 2009 a 2014 především v Salonu Práva - Jiř́ího Přibáně [2014] ale dokládají, že současný liberalismus má svého konzistentního mluvčího i v domácí debatě. Přibáňùv liberalismus rozhodně nereprodukuje monotematismus svého tržního rivala, zároveň ale pevně stojí na individuální autonomii, která se $\mathrm{v}$ autorově perspektivě může smysluplně rozvíjet jen $\mathrm{v}$ rámci fungujícího společenství morálně rovných jedinců. Přibáň [ibid.: 14-15] se kriticky vymezuje proti všem podobám „politického existencialismu, který neustále převádí problémy politického rozhodování a ústavnosti na otázky kulturní existence a národního osudu. Jako kdyby hlavním, ne-li jediným úkolem budování ústavního státu mělo být národní sebeurčení a nalezení jakéhosi autentického bytí, a ne vytvoření reprezentativní vlády omezené občanskými právy a svobodami."

Na rozdíl od mystického hledání utopie lásky a nekonečnosti nám tak Přibáň ve svých úvahách dává možnost nahlédnout, jak lze z koherentně liberálního - nikoli však naivně atomistického - hlediska intelektuálně-prakticky řešit konkrétní otázky našeho politického společenství. V Přibáňově pojetí nejsme odsouzeni hledat své vlastní štěstí sami nebo v osamění náboženské kontemplace, ale $\mathrm{v}$ dialogu a komunikaci s druhými, které habermasovsky uznáváme jako rovné, pokud oni uznávají nás. V jeho liberálním pojetí jsme tak bezesporu sociální, tj. komunikující, bytosti ve společnosti, která se potýká s konkrétními problémy současnosti, at' už pramení doma, nebo za (nominálními) hranicemi našeho společenství.

Tuto společnost tvoříme jako morálně rovné osoby, které se politicky realizují jen jednou částí svých já. Mimo politiku budujeme smysl své existence $\mathrm{v}$ mnoha dalších společenských sférách. A $\mathrm{k}$ tomu potřebujeme, aby byly naplněny základní sociálně-ekonomické podmínky. Ve své kritice Nečasovy vlády tak autor nezapomene zdůraznit, že každá vláda „,by měla ve svých reformách stále vycházet $\mathrm{z}$ toho, co věděli již liberálové a demokraté na konci 19. století a z čeho později vznikla koncepce sociálního občanství“ [ibid.: 137]. Přibáň pak ukazu- 
je, co v konkrétních otázkách znamená tato východiska koherentně aplikovat, přičemž erozi sociálního občanství považuje za jeden z nejpalčivějších problémů dneška.

Obecně a v souladu se svými sociálně-liberálními východisky Přibáň [ibid.: 103] upozorňuje na to, že řešení krize a nestability demokratické společnosti „,nespočívají v posílení jednoty demokratického národa, jeho společné identity, ideologických kořenů“. Kontinuální řešení krizí definuje samu podstatu demokracie a neposouvá ji to a priori $\mathrm{k}$ tomu, aby vyhlašovala výjimečný stav nebo spoléhala na mobilizaci obrodných hnutí v čele s proroky lásky. Řešení se nacházejí v institucích, nikoli v obecné vůli, nebo dokonce emoci.

Podle Přibáně [ibid.] jednak máme „„časové omezení mandátu vlády“, které umožňuje nositele nefungujících návrhů řešení společenských problémů civilizovaně nahradit jinými, dále se můžeme spolehnout na „ústavní omezení výkonu každé vlády“" které poskytuje jednotlivcưm možnost domoci se svých práv i proti demokraticky zvolené většině, a za třetí žijeme ve společnosti, kde je politika „pouze jednou z mnoha oblastí moderního života, a proto nemůže regulovat společnost $\mathrm{v}$ její totalitě“. Otázky lásky a spásy v takové společnosti typicky zůstávají vně toho, co považujeme za politické, a realizují se nejen v soukromé sféře, ale také v rámci dobrovolných uskupení občanské společnosti. Naše potřeba po splynutí s druhými tím ztrácí svưj potenciálně utlačující moment.

\section{Pospolu v občanské společnosti}

Nejen liberál Přibáň [ibid.: např. 55-62], ale i řada komunitaristů nachází právě v této sféře dobrovolné spolupráce prostor jak pro realizaci aktivního občanství, tak také nadindividuálních a transcendentních impulsů moderního člověka [Walzer 1995; Sandel 1996: 317-350]. Není asi náhodou, že v Drulákově knize se toho o občanské společnosti mnoho nedočteme. S kolektivně konstituovanou mnohostí se nepočítá. Pojednání kolektivní koordinace se vyčerpává v mystické koncepci celospolečensky obrodného hnutí. Prostor svobodného sdružování je tím vlastně konceptuálně zrušen, protože se od něj očekává rovnou celková proměna společnosti. Veřejná sféra se explicitně politizuje podle jednoho vzorce, který formuluje byț vnitřně funkčně strukturovaná, tak jednotná elita obrodného hnutí: „Z toho vzejde elita hnutí, která se postaví politicko-ekonomické elitě stávajícího řádu. Nejde však o pouhé stř́íání stráží, v němž po jedněch kořistnících následují druzí, jako tomu bývá v obvyklých demokratických volbách či korporátních bitvách." [Drulák 2012: 293] Nejde o obvyklou demokratickou proceduru, začíná konzervativní revoluce.

Oba autoři se shodují v tom, že bratrství vidí jako neaktualizovanou možnost politické modernity s jejími třemi konstitutivními hodnotami. Zatímco Drulák chce bratrství plně rehabilitovat (jak jsme viděli, i na úkor svobody a morální rovnosti), Přibáň naopak upozorňuje na nezvladatelná nebezpečí, která by to přines- 
lo. Ačkoli se bratrství na rozdíl od svobody a rovnosti nestalo stavebním kamenem moderních ústavních uspořádaní [srov. Baroš 2013], neznamená to zároveň, že by z moderní společnosti zmizelo. Když odhlédneme od liberálního nacionalismu, jeho vyjádření, které je jedině v souladu s lidskou důstojností, svobodou a morální rovností, můžeme najít ve sféře svobodného sdružování, kterou obvykle označujeme jako občanskou společnost. Jak upozorňuje například J. Habermas [(1992) 1996], ačkoli se na jejím půdorysu formulují společenské alternativy, které zde také usilují o veřejnou podporu, mezi tímto procesem utváření veřejného mínění, z něhož politická rozhodnutí v posledku čerpají svou legitimitu, a procesem utváření politické vưle (v rámci institucí státu) musí zůstat zachován rozdíl. Habermas tak vyžaduje především místo pro veřejnou sféru neformální komunikace.

Ani náznakem se zde ale nejedná o jednoznačnou odpověd. Naopak - stále zůstává obrovský prostor pro to, abychom se mohli smysluplně bavit o tom, jak by takový prostor měl vypadat, jak by měl být regulován a jaké funkce by měl plnit. Na tento prostor, který v naší diskusi Drulák zcela přehlíží a $\mathrm{k}$ němuž Přibáň přistupuje ze sociálně-liberálního hlediska, se koneckoncủ zaměřuje podstatná část současných debat ve společenských vědách [srov. např. Císař 2015]. A škála různých odpovědí sahá od levice [viz např. Barša, Císař 2004] přes moderní realistický liberalismus [např. Barša, Císař 2008; Dalton 2008] až ke spíše konzervativnímu výkladu [např. Putnam 2000].

Tyto diskuse na jedné straně dávají možnost otázku bratrství smysluplně otevřít, na straně druhé nás nenutí sklouzávat do revolučního romantismu. Jak v úvodu k Přibáňově knize píše Eliška Wagnerová [Přibáň 2014: 11]: „Mnohem víc než slavnostním proklamacím o navždy platných velkých hodnotách, které spojují Evropany, věří Jiří Přibáň v utváření evropské občanské společnosti a jejích vlastních struktur. [...] Přibáňův pohled je totiž charakterizován realismem a nic mu není vzdálenějš́ího než romantismus." A právě proto může řešit komplexní problémy současnosti včetně např́klad nejasné budoucnosti demokracie, evropské integrace či mocenských asymetrií způsobovaných globálním kapitalismem bez toho, že by sklouzával ke zjednodušující viřre, že nás z nich vysvobodí realizace jednoho principu či abstraktní hodnoty.

Ondřej Císar̆

\section{Literatura}

Baroš, J. 2013. Mezi lidskými právy a suverenitou - koncepty politické filosofie a jejich aplikace $v$ realitě České republiky [online]. Disertační práce. Brno: Masarykova universita [cit. 12. 2. 2015]. Dostupné z: http://is.muni.cz/th/61269/fss_d/.

Barša, P. 1995. „Individualismus a komunitarismus. Americké diskuse o liberalismu a hodnotě společenství." Politologický časopis 2 (3): 192-206.

Barša, P., O. Císař. 2004. Levice v postrevoluční době: Občanská společnost a nová sociální hnutí $v$ radikální politické teorii 20. století. Brno: CDK.

Barša, P., O. Císař. 2008. Anarchie a řád ve světové politice. Kapitoly z teorie mezinárodních vztahư. Praha: Portál. 
Císař, O. 2005. „Filosofické základy studia politického pluralismu.“ Politologický časopis 12 (2): 201-212.

Císař, O. 2015 v tisku. „Social Movements in Political Science.“ In: D. della Porta, M. Diani (eds.): Oxford Handbook of Social Movements [online]. Oxford: Oxford University Press. Dostupné z: http://www.oxfordhandbooks.com/view/10.1093/ oxfordhb/9780199678402.001.0001/oxfordhb-9780199678402-e-12.

Dalton, R. 2008. Citizen Politics. Public Opinion and Political Parties in Advanced Industrial Democracies. Washington, DC: CQ Press.

Drulák, P. 2012. Politika nezájmu: Česko a Západ v krizi. Praha: Sociologické nakladatelství (SLON).

Drulák, P. 2013. „O politicích a prorocích.“ Novinky.cz [online]. [cit. 12. 2. 2015]. Dostupné z: http://www.novinky.cz/kultura/salon/299814-petr-drulak-o-politicich-aprorocich.html.

Habermas, J. (1992) 1996. Between Facts and Norms. Contributions to a Discourse Theory of Law and Democracy. Cambridge, Mass.: The MIT Press.

Kymlicka, W. 2002. Contemporary Political Philosophy. An Introduction. 2nd edition. Oxford, New York: Oxford University Press.

MacIntyre, A. (1981) 2004. Ztráta ctnosti. K morální krizi současnosti. Praha: Oikoymenh.

Marks, G., L. Hooghe, M. Nelson, E. Edwards. 2006. „Party Competition and European Integration in the East and West. Different Structure, Same Casuality." Comparative Political Studies 39 (2): 155-175.

Mulhall, S., A. Swift. 1992. Liberals and Communitarians. Oxford, Malden: Blackwell.

Putnam, R. 2000. Bowling Alone: The Collapse and Revival of American Community. New York, London: Simon \& Schuster.

Přibáň, J. 2011. „O dobru a spravedlnosti: Odpověd’ Pavlu Holländerovi.“ Pp. 42-47 in J. Přibán̆, P. Holländer et al. Právo a dobro v ústavní demokracii. Polemické a kritické úvahy. Praha: Sociologické nakladatelství (SLON).

Přibáň, J. 2014. Obrana ústavnosti aneb Česká otázka v postnacionální Evropě. Praha: Sociologické nakladatelství (SLON).

Přibáň, J., P. Holländer et al. 2011. Právo a dobro v ústavní demokracii. Polemické a kritické úvahy. Praha: Sociologické nakladatelství (SLON).

Rawls, J. 1971. A Theory of Justice. Oxford: Oxford University Press.

Rawls, J. 1993. Political Liberalism. New York: Columbia University Press.

Rawls, J. (1985) 1995. „Spravedlnost jakožto ,fairness': politická, nikoliv metafyzická.“ Reflexe 14: 71-100.

Rawls, J. (1989) 2003. „Oblast politična a překrývající konsensus.“ Reflexe 24: 41-67.

Rovny, J., E. Edwards. 2012. „Struggle over Dimensionality: Party Competition in Western and Eastern Europe." East European Politics and Societies 26 (1): 56-74.

Sandel, M. 1982. Liberalism and the Limits of Justice. Cambridge: Cambridge University Press.

Sandel, M. 1996. Democracy's Discontent. America in Search of Public Philosophy. Cambridge, London: The Belknap Press of Harvard University Press.

Swift, A. (2001) 2005. Politická filozofie: Základní otázky moderní politologie. Praha: Portál.

Taylor, Ch. (1989) 1997. „Nedorozumění v diskusi mezi liberály a komunitaristy." Pp. 465-494 in J. Kis (ed.). Současná politická filosofie. Praha: Oikoymenh.

Taylor, Ch. (1992) 2001. Etika autenticity. Praha: Filosofia.

Walzer, M. 1983. Spheres of Justice. A Defense of Pluralism and Equality. Basic Books.

Walzer, M. (ed.). 1995. Toward a Global Civil Society. Berghahn Books.

Weber, M. (1919) 1998. „Věda jako povolání.“ Pp. 109-134 in M. Havelka (ed.). Metodologie, sociologie a politika. Praha: Oikoymenh. 